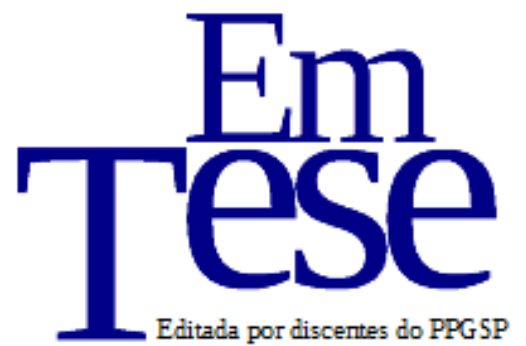

\title{
Quebrando relógios, desconstruindo identidades, buscando a justiça (se é que ela é possível): pensando (n)os limites com Jacques Derrida e Walter Benjamin $^{1}$
}

Resumo: Este artigo tem como objetivo investigar de que forma Walter Benjamin e Jacques Derrida interpretam os conceitos de identidade, justiça e história. Também é importante analisar como, na visão desses autores, esses conceitos se relacionam e como as interpretações desses autores se aproximam ou se afastam. É a partir do trabalho sobre os limites que esses autores parecem desenvolver suas principais teses e é sobre esse ponto que esse artigo se debruça para abrir novas questões e tentar descobrir novos caminhos para refletir sobre aqueles conceitos apontados no início.

Palavras-chave: identidade, justiça, história, limite, Walter Benjamin, Jacques Derrida.

\section{Breaking clocks, deconstructing identities, seeking justice (if it is possible): thinking of (on) the limits with Jacques Derrida and Walter Benjamin}

\begin{abstract}
This article aims to investigate how Walter Benjamin and Jacques Derrida interpret the concepts of identity, justice and history. It is also important to analyze how, in the view of these authors, these concepts are related and how these two interpretations are similar or different. It is from this work on the limits that these authors seem to develop their main theses and it is on this point that this article try to open new questions and try to find new ways to think about those concepts pointed out in the beginning of this abstract.
\end{abstract}

Keiwords : identity, justice, history, limit, Walter Benjamin, Jacques Derrida.

\footnotetext{
1 (c) EY Esta obra está licenciada com uma Licença Creative Commons Atribuição 4.0 Internacional.

${ }^{2}$ Doutorando do Programa de Pós-graduação em Sociologia da Universidade Federal de Pernambuco (UFPE). Email: filipe.barreiros@ hotmail.com
} 


\section{Introdução}

A consciência de destruir o contínuo da história é própria das classes revolucionárias no momento da sua ação. A grande Revolução introduziu um novo calendário. $O$ dia com que se inicia um calendário funciona como um dispositivo de concentração do tempo histórico. Eé, no fundo, sempre o mesmo dia que se repete, sob a forma dos dias e feriados, que são dias de comemoração. Isso quer dizer que os calendários não contam o tempo como os relógios. São monumentos de uma consciência histórica da qual parecem ter desaparecido todos os vestígios na Europa dos últimos cem anos. Na revolução de julho aconteceu ainda um incidente em que essa consciência ganhou expressão. Chegada a noite do primeiro dia de luta, aconteceu que, em vários locais de Paris, várias pessoas, independentemente umas das outras e ao mesmo tempo, começaram a disparar contra os relógios das torres. Uma testemunha ocular, que talvez deva seu poder divinatório à força da rima, escreveu nessa altura: (...)

[Incrivel! Irritados, com a hora, dir-se-ia, os novos Josués, aos pés de cada torre, alvejam os relógios, para suspender o dia.]

(BENJAMIN, 2012b, p. 18)

A citação acima é a décima quinta tese sobre o conceito da história, parte de uma série de pequenos, porém ricos, textos de Walter Benjamin. No trecho destacado, Benjamin chama atenção para um evento ocorrido na revolução de julho de 1830, na qual manifestantes, em diversas partes de Paris, direcionaram sua revolta para os relógios da cidade. Essa atitude, que a princípio pode parecer ingênua e sem lógica, para Benjamin, ao contrário, representa algo muito significativo e digno de toda atenção. Em sua teoria, a narração da história, ou melhor, essa narrativa em sua forma contínua, representada pelo tempo cronológico, medido pelo relógio, diz respeito a um instrumento fundamental dos grupos opressores para a manutenção de seu domínio e para a submissão dos derrotados. Por isso, o autor inicia seu texto dando tanta importância à atitude destacada: "A consciência de destruir o contínuo da história é própria das classes revolucionárias no momento de sua ação”.

Em abril do ano 2000, às vésperas das comemorações oficiais do quinto centenário da "descoberta" do Brasil, ocorreu outro evento semelhante. Durante manifestações populares (organizadas por grupos sindicais operários e camponeses, movimentos negros e indígenas) contrárias às comemorações oficiais organizadas pelo governo, um grupo de índios atirou flechas contra um relógio (patrocinado pela Rede Globo) que fazia a contagem regressiva para os quinhentos anos do Brasil (LÖWY, 2005). Esse evento, certamente seria muito significativo aos olhos de Benjamin e ajuda a dar mais relevo às questões que guiarão esse texto. Diante dos exemplos citados é possível notar que a disputa em torno da história representa ponto fundamental para o autor. Se a forma como ela é contada significa uma forma de violência e submissão, a transformação da maneira de narrá-la, a quebra e a 
interrupção da continuidade do tempo cronológico, devem ser armas fundamentais a serem empunhadas pelos vencidos. São maneiras de conceber outra história, outra experiência, um tempo e um lugar aptos para a entrada de outras possibilidades, para almejar uma sociedade justa ou feliz.

Questões muito semelhantes foram fundamentais para a construção da obra e do pensamento de Jacques Derrida, autor franco-argelino que escreveu posteriormente a Benjamin. As preocupações com as relações entre história, justiça e o aparecimento do outro são pilares de sustentação para toda a reflexão desse pensador. Parece-me, contudo, que não são apenas as questões que são semelhantes entre esses autores. A maneira como ambos buscam concatená-las e respondê-las, a meu ver, também se aproxima em vários pontos. Pode-se dizer que os dois pensadores poderiam ser designados como sujeitos que elaboraram suas reflexões sempre no limite, pensando os limites, tentando sempre superá-los, buscando brechas e fraturas nas fronteiras, pequenas aberturas para outras possibilidades.

John Caputo, importante comentador do pensamento derridiano, em seu livro "Deconstruction in a nutshell" (1997), aponta para a simpatia do autor em trabalhar sempre a partir das contradições, das aporias, dos limites, daqueles lugares em que a aparente impossibilidade de saída é o que move e é capaz de alargar as possibilidades. Walter Benjamin, a partir da minha interpretação, parece compartilhar também do gosto de enxergar saídas nas contradições, nos lugares em que o caminho parece fechado. É preciso adiantar o que chamo de pensamento do limite: a forma de reflexão que se preocupa menos com as essências, com as origens (no sentido de marco fundador), com o centro, do que com o que é posto nas margens, nas fronteiras, com o que é expulso pelas essências, pelas origens.

Para desenvolver este artigo, iniciarei expondo as principais ideias de Derrida sobre os temas centrais a serem tratados (vinda do outro/identidade, justiça e história) e suas relações. Em seguida trarei elementos da análise benjaminiana que podem ajudar a iluminar a relação entre esses temas, assim como a reflexão sobre sua posição como um pensador do limite. A partir das apresentações dos pensamentos desses autores, será importante tentar perceber como as reflexões feitas a partir dos limites não representam apenas grandes voos teóricos, mas podem contribuir politicamente com a busca da justiça, com a narrativa da história dos vencidos e com a vinda do completamente outro. Em minha conclusão, tentarei refletir brevemente sobre a ideia do projeto da nação brasileira, suas relações com os temas tratados e retomarei os episódios das quebras dos relógios para pensar nas (im)possibilidades de justiça relacionadas a esse projeto de nação. 
Com isso, é possível dizer que o objetivo deste artigo é refletir sobre as relações entre os conceitos de identidade, história e justiça e de que maneira as reflexões derridianas e benjaminianas podem contribuir para percebermos suas (i)limitadas (im)possibilidades. $\mathrm{O}$ confronto das interpretações desses dois autores permite estabelecer comparações e complementaridades, algo que contribui para tencionar ainda mais os conceitos apontados.

\section{Jacques Derrida, as possibilidades impossíveis e vice-versa}

Não é uma tarefa fácil ler e trabalhar com esses pensadores do limite. Derrida e Benjamin foram autores para os quais as categorias e conceitos à disposição pareciam insuficientes para exprimir o que eles realmente gostariam de dizer. Ambos operavam com torções dos conceitos para expressar, através deles, significados escondidos ou opostos ao que pareciam. Os conceitos também eram trabalhados em seus limites, em suas contradições, em suas reveladoras impossibilidades. Diante dessa difícil tarefa, contarei com o auxílio de importantes comentadores da obra desses autores para tentar dar conta de tamanha complexidade. John Caputo, com seu já referido livro "Deconstruction in a nutshell", será uma fonte fundamental na empreitada de apresentar o pensamento derridiano. Neste livro, o comentador trabalha sobre a concepção do limite e sintetiza a forma como Derrida enxerga os tópicos a serem abordados.

Já que falei sobre a simpatia de Derrida em torcer os conceitos, extrair deles o que a princípio parecem não expressar e, a partir disso, reconfigurá-los, é possível começar com sua importante interpretação sobre a noção de comunidade. Para ele, a ideia de comunidade, que em uma primeira leitura, é sinônimo de fraternidade, de solidariedade, de partilha, guardaria em si o seu oposto. A etimologia desse vocábulo apontaria para isso: de origem militar, communio, aproxima-se da palavra munição. "Ter uma communio é estar fortificado por todos os lados, construir uma 'comum' (com) defesa (munis), como quando um muro é colocado ao redor de uma cidade para protegê-la do estranho ou do estrangeiro" (CAPUTO, 1997, p. 108) 3 .

Esse fechamento, implícito na ideia de comunidade, é diametralmente oposto à teoria filosófico-política da desconstrução, defendida por Derrida. A ideia de desconstrução subjaz toda a obra derridiana sob múltiplas facetas, mas, para Caputo, ela poderia ser resumida como uma constante preocupação com a vinda do outro, com a abertura para a recepção do

\footnotetext{
3 Todas as traduções foram feitas por mim.
} 
totalmente outro; nesse sentido, toda operação desconstrucionista de Derrida procura abrir espaços para a chegada do outro, do diferente. Por isso, a concepção de comunidade, como uma fortaleza que dificulta a chegada do estrangeiro é algo que deve ser desconstruído.

A concepção de hospitalidade também é trabalhada por Derrida e fornece outras ideias interessantes. É um conceito que parece agradar mais ao autor, por significar dar as boas vindas ao estrangeiro, ao que vem de fora. Mesmo assim, no entanto, o conceito também será trabalhado em seus paradoxos. A palavra hospitalidade deriva de hospes, formada a partir de hostis, que significa estrangeiro, e depois se tornou inimigo ou hostil estrangeiro (hostilis) + pets (potis, potes, potentia) de ter poder. Sendo assim, "dar as boas vindas é sempre uma função do poder do anfitrião de permanecer mestre das premissas" (CAPUTO, 1997, p. 110). Ou seja, há sempre uma auto-limitação na ideia de hospitalidade, pois esta pressupõe uma distância entre ter a propriedade e convidar o outro para a sua casa. Só é possível ser anfitrião em sua propriedade, o que mostra que sempre há um pouco de hostilidade na hospitalidade.

Porém, essa tensão entre receber alguém e manter a soberania não é negativa; é, ao contrário, o que possibilita a hospitalidade. E aqui, Derrida mostra como é um pensador do limite, da contradição, da aporia, porque o que possibilita a hospitalidade é, justamente, a sua impossibilidade. A hospitalidade só acontece quando ela é forçada a ir além dela, mas isso é impossível. Derrida, então, aposta na ideia de uma hospitalidade por vir. Se esse não for o objetivo, a hospitalidade corre o risco de cair nela mesma e, assim, se voltar para seu significado hostil. É preciso, então, forçar os limites, encontrar soluções parciais, já que as soluções totais correm o forte risco de serem hostis. O anfitrião só será um verdadeiro anfitrião quando deixar de sê-lo, em um momento de loucura, em sua precariedade. É esse momento fugidio que deve ser aproveitado para abrir uma brecha e permitir a entrada do outro. É preciso, portanto, na comunidade e na hospitalidade, perceber suas impossibilidades para forçar seus limites (CAPUTO, 1997).

Nas entrelinhas desses dois conceitos, está outro que será relevante para o desenvolvimento deste trabalho: a identidade. A importância desse conceito fica clara se refletirmos sobre o seu significado. Identidade diz respeito ao que é idêntico, ao que une. Semelhantemente à comunidade, no entanto, deixa implícito o seu oposto, a noção de diferença. Portanto, identificar significa, também, diferenciar. Essa concepção de identidade homogênea ou auto-idêntica é, para Derrida, um grande perigo. Mesmo atento a esse perigo, o autor não renuncia à noção de identidade cultural, mas tenta desconstrui-la, torná-la aberta para a diferença. Propõe uma identidade baseada numa cultura de auto-diferenciação, na qual a identidade seja efeito da diferença. 
Em seu livro "The gift of death" (1995), Derrida expõe essa ideia em uma frase aparentemente simples, mas que guarda, para ele, um significado muito importante. A frase é: "Todo outro é todo outro". Num primeiro olhar, essa frase representa uma obviedade, uma tautologia; Derrida, no entanto, aponta para a possibilidade de dois sentidos diferentes para a palavra "todo". Ela pode ter o sentido de "cada um", "alguém", ou o sentido de "totalmente", "completamente", "absolutamente". Com esses novos significados a frase deixa de ser uma tautologia e passa a ser uma "heterologia". Contudo, a frase em questão guarda em si uma repetição, uma monotonia. A tautologia não consegue ser totalmente rompida e um princípio de identidade subjaz na sentença. Diz o próprio Derrida (1995, p. 83):

os dois outros são repetidos na monotonia de uma tautologia que vence no final das contas, a monotonia do princípio da identidade que, graças a junção e ao sentido do ser, assumiria aqui a alteridade ela mesma, nada menos que isso, na tentativa de dizer: o outro é o outro, o que é sempre a alteridade do outro é sempre a alteridade do outro. E o segredo dessa fórmula se fecharia sobre uma especulação heterotautológica que sempre se arrisca a não significar nada.

Essa breve sentença impulsiona o que Derrida concebe como uma identidade baseada na auto-diferenciação, com uma identidade que é efeito da diferença. $\mathrm{O}$ autor está buscando uma identidade que não seja capaz de se fechar em si, que guarde sempre espaço para o outro, ou seja, uma identidade constituída pelo todo outro.

Para marcar o que ele quer dizer com uma cultura que articula diferença, Derrida se refere a um termo da navegação que é "the Other Heading" (CAPUTO, 1997, p. 117). Com isso, ele quer apontar para uma atenção à conduta do outro, uma atitude de voltar-se constantemente para o outro, de ser mais receptivo. Além disso, o autor pretende se referir a algo que esteja além de uma direção, ou seja, outra coisa que não signifique um planejamento para frente, mas que esteja aberta ao futuro, ao que pode vir e que não se prenda a uma teleologia.

Em uma cultura de identidade, que mantém sua direção teleológica, uma "arché" se dirige resolutamente em direção ao seu próprio telos inscrito sob sua pele, reunindo nele mesmo para ele mesmo tudo o mais profundamente em uma unidade arqueo-teleo-lógica que "se torna a si mesma". O truque da desconstrução é manter sua cabeça sem um direcionamento (CAPUTO, 1997, p. 116).

A partir disso é possível notar um primeiro esboço de um conceito derridiano de história. Ele se livra de uma direção teleológica e desenvolve uma concepção mais livre dos acontecimentos históricos. Para que uma cultura esteja aberta ao que virá, é preciso que ela 
não se atenha a uma direção, visto que isso pode representar uma repetição de si mesma, de sua "archê" que sempre buscará sua auto-realização no futuro, o que dificultaria bastante a vinda do outro. É relevante notar aqui como sua concepção de história se relaciona com a forma de lidar com o outro. Manter um fim, um direcionamento, significaria manter uma continuidade, uma repetição de si, do idêntico e isso é não se abrir para as possibilidades de vinda do outro. Para Derrida, essa atitude deve ser evitada, por isso reivindica uma história não teleológica (CAPUTO, 1997).

Com isso em vista, o que Derrida pretendia dizer quando se referia à "identidade" ou à "comunidade" era uma tentativa de suportar suas tensões constituidoras sem possuir uma regra já pré-estabelecida para resolvê-las. E não haveria nada que pudesse lhes dar uma direção, pois não há uma essência de onde partem e que pudesse legitimar essa direção. Dessa maneira, as coisas estariam sempre abertas. O sentido de uma comunidade, se ela existe, é a abertura ao outro e para algo que não se encaixe em uma direção. Tudo isso se refere a uma busca da democracia, mas uma democracia sempre por vir, que nunca se realizará. Há, portanto, o desejo de uma comunidade por se formar, mas também por conhecer seus limites, para que esses limites possam ser a sua abertura. Por isso, por saber que as possibilidades dessa comunidade estão em seus limites, Derrida reivindica uma comunidade fraca, uma comunidade sem comunidade, uma comunidade que se diferencia de si mesma, baseada, portanto na impossibilidade de se constituir como uma comunidade (CAPUTO, 1997).

Quando Derrida fala sobre a busca por uma comunidade aberta para o outro, ele está falando, em outras palavras, sobre uma busca por justiça, por uma convivência em uma sociedade justa. Muito se falou e criticou Derrida pelo suposto caráter violento, destrutivo e negativo da desconstrução. Porém, como bem apontado por Caputo, trata-se de uma crítica ilegítima, que não consegue apreender que a desconstrução é sempre feita em nome de algo indesconstrutível. Isso que é indesconstrutível é a justiça. Algo importante de ser destacado é a diferença entre lei e justiça. A primeira se refere às estruturas positivas dos sistemas judiciais e são passíveis de desconstrução, porque são construídas. Isso que pode parecer ruim é, para Derrida, uma boa notícia, visto que a desconstrutibilidade seria condição para o aperfeiçoamento da lei.

$\mathrm{Na}$ estrutura que assim descrevo, o direito é essencialmente desconstrutível, ou porque ele é fundado, isto é, construído sobre camadas textuais interpretáveis e transformáveis (e esta é a história do direito, a possível e necessária transformação, por vezes a melhora do direito), ou porque seu fundamento último, por definição não é fundado. Que o direito seja desconstrutível não é uma infelicidade. Pode-se 
mesmo encontrar nisso a chance política de todo progresso histórico (DERRIDA, 2010, p. 27).

Essa desconstrutibilidade da lei permite manter a atenção constante para o outro, que a lei é incapaz de perceber. John Caputo aponta, porém, que na obra de Derrida essa desconstrutibilidade da lei é inseparável da indesconstrutibilidade da justiça.

Justiça não é desconstrutível, afinal nem tudo é desconstrutível, ou não haveria ponto para a desconstrução. Enquanto é verdade que não há um fim para a desconstrução, não há um telos, nem um eschaton, não é verdade que não há ponto para a desconstrução, não há um estímulo, impulso, não há uma ponta. Nem tudo pode ser desconstrutível, ou melhor todas as coisas podem ser desconstruídas, mas justiça, se tal coisa existe, ela não é uma coisa. Justiça não é uma entidade presente ou uma ordem, não é uma realidade existente ou um regime; nem é um ideal em direção ao qual nós descemos à Terra e contemplamos sua forma divina. Justiça é uma expectativa absolutamente imprevisível (um paradoxo paralisante) em virtude da qual as coisas que se desconstroem são desconstruídas (CAPUTO, 1997, p. 132).

Assim, o que Caputo quer mostrar é que a visão da desconstrução como pura negatividade ou destruição é um erro de leitura. Contudo, isso não significa que a justiça seja o estabelecimento de uma direção ou de um telos, já que ele fala de uma expectativa imprevisível, de algo que está por vir. A desconstrução não assenta visões de justiça como objetivo, como horizonte possível. Para Derrida, o possível é aquilo que pode ser previsível ou projetável, é o "futuro-presente", aquele que com sorte e trabalho se alcançará; um futuro sempre posto como ideal.

Esse futuro possível não é desejável para Derrida. Ele está preocupado com o futuro impossível, com o por vir. Mas como pensar o futuro em sua impossibilidade? Para o autor, desejar esse futuro impossível significa ir contra os limites do constrangimento previsível e, assim, ser capaz de vislumbrar outras realidades. De certa maneira, a justiça só é possível em sua impossibilidade, em sua aporia. Só pode haver justiça quando o caminho está bloqueado, porque se o caminho está livre o que se faz é aplicar leis mecanicamente, mantendo a segurança do que já está dado. Sobre a justiça, Derrida aponta para algo interessante: para ele, não há nenhum lugar que esteja simplesmente fora da lei, nenhum lugar para ser procurado e achado, pois não há justiça pura. Ela é impossível.

No entanto, essa impossibilidade da justiça não pode ser paralisante. É preciso que as aporias sejam encaradas e que a própria impossibilidade seja motor de busca por justiça. Diz Derrida (2010, p. 55): 
Esse excesso da justiça sobre o direito e sobre o cálculo, esse transbordamento do inapresentável sobre o determinável não pode e não deve servir de álibi para a abstenção das lutas jurídico-políticas no interior de uma instituição ou de um Estado, entre instituições ou entre Estados. Abandonada a si mesma, a ideia incalculável e doadora da justiça está sempre mais perto do mal, ou do pior, pois ela pode sempre ser reapropriada pelo mais perverso dos cálculos. (...) A justiça incalculável manda calcular.

Já é possível notar como os conceitos que mais interessam a este trabalho começam a se relacionar no pensamento de Derrida. A justiça, que não pode se confundir com um telos, assim como sua concepção de história, são pensadas para garantir uma identidade porosa, heterogênea, sempre aberta para o outro. Essa preocupação central de Derrida é que funciona como a linha que costura aqueles conceitos. Ao longo do trabalho isso ainda será tratado com mais afinco.

Antes de passar para a concepção derridiana de história, porém, falarei um pouco do seu trabalho sobre a ideia de perdão. Faço isso, tendo em vista que esse conceito é capaz de ligar sua discussão sobre a justiça com a de temporalidade. Para Derrida (2001, p. 32):

o tempo todo o perdão está a serviço de uma finalidade, mesmo que seja ela nobre e espiritual (redenção, reconciliação, salvação), o tempo todo ela busca reestabelecer uma normalidade (social, nacional, política, psicológica) por um trabalho de luto, por alguma terapia ou ecologia da memória, então o "perdão" não é puro - nem é o seu conceito. O perdão não é, ou não deveria ser, normal, normativo, normalizador. Ele deveria permanecer excepcional e extraordinário, em face do impossível: como se interrompesse o curso ordinário de uma temporalidade histórica.

Inspirado a partir de uma tradição religiosa abraâmica, o autor afirma, então, que o verdadeiro perdão é aquele que perdoa o que não pode ser perdoado. E aqui Derrida aporta em seu terreno favorito: o da aporia. Ao considerar que o perdão só é o perdão do imperdoável, o perdão, então, é impossível. Sendo assim, não pode ser confundido com ideias como arrependimento, pedidos de desculpas, anistia. $\mathrm{O}$ perdão não poderia pedir nada em troca e nem impor condições, por que quando faz isso deixa de se referir ao ato em questão. Passa a se tornar uma moeda de troca. Perdoar e exigir que alguém mude são ações contraditórias aos olhos de Derrida. Quem estaria sendo perdoado seria o "novo" sujeito e não o "antigo culpado". Por isso o verdadeiro perdão é impossível.

Além de não poder esperar nada em troca, o verdadeiro perdão deve ser fruto de uma relação entre vítima e culpado. Contudo, outra instância como a lei, o Estado quase sempre intervém nessa relação. Nesse caso, pode-se falar de reparação, anistia etc., mas não de 
perdão. Uma terceira instância não pode perdoar pela vítima. Derrida (2001, p. 43) exemplifica isso com um episódio que ocorreu durante a realização do comitê da verdade na África do Sul. Uma mulher, cujo marido havia sido assassinado por torturadores da polícia foi chamada a testemunhar e disse algo como: "uma comissão ou um governo não podem perdoar. Só eu, eventualmente, poderia fazer isso (e eu não estou pronta para perdoar)”. Nesse sentido, só quem é capaz de perdoar é a própria vítima. Nenhuma outra instituição pode perdoar pela vítima. Até isso é posto em xeque por Derrida, visto que, para ele, sempre haverá algum outro polo entre a vítima e o culpado, seja o Estado, a lei, alguma instituição, a linguagem. É nesse sentido, também, que o perdão sempre será impossível.

Mas o que resta fazer? Esquecer as maiores atrocidades e perdoar sem exigir nada em troca? Não se deve cobrar nenhuma reparação? Isso também não seria injusto? Derrida aponta que, na tradição religiosa, há vezes em que o perdão é dado sem troca e sem condição, mas outras vezes é necessário o arrependimento ou a transformação daquele que cometeu o pecado. Essa tensão é importante para o autor e é a partir dela que ele tenta fornecer explicações para as últimas questões:

Se nossa ideia de perdão é arruinada assim que é privada do seu polo de referência absoluta, nomeadamente sua pureza incondicional, ela permanece, no entanto, inseparável do que é heterogêneo a ela, nomeadamente a ordem das condições, arrependimento, transformação, tantas coisas quantas a permitem inscrever-se na história, na lei, na política, na existência em si mesma (DERRIDA, 2001, p. 45).

Ou seja, há um movimento duplo entre o perdão e a política. Por um lado, eles são irredutíveis, um não se confunde com o outro, são absolutamente heterogêneos. No entanto, são indissociáveis.

Se se quer, e isso é necessário, que o perdão se torne efetivo, concreto, histórico; se se quer que isso chegue, que aconteça pela mudança das coisas, é necessário que essa pureza se engaje ela mesma em uma série de condições de todos os tipos (psico-sociológica, política, etc.) (DERRIDA, 2001, p. 45).

Essa discussão se assemelha bastante à reflexão derridiana acerca da relação entre a justiça e a lei. A justiça, assim como o perdão, é impossível. Para Derrida, a justiça e a ética devem ser guiadas pela possibilidade de acolhimento do outro, de oferecer hospitalidade para o outro, para o diferente. A justiça depende do amor e do acolhimento total e irrestrito ao completamente outro. No entanto, é impossível atingir plenamente a justiça, dentre outras razões, porque no momento em que ela fosse atingida e algo fosse afirmado como justo, ao 
mesmo tempo uma fronteira seria criada compondo o que seria considerado injusto. Isso, por si só, impede o acolhimento do completamente outro, fecha-se para o que é diferente. De certa maneira, a justiça só é possível em sua impossibilidade, em sua aporia. Como já foi dito, só pode haver justiça quando o caminho está bloqueado, pois se o caminho está livre o que se faz é aplicar leis automaticamente, mantendo o que já é estabelecido.

De forma semelhante, Derrida não é contra a reparação, ou a reconciliação, ele só quer dizer que esses conceitos não podem ser confundidos com o perdão. Um perdão que seja finalizado não é perdão, afinal como já mencionado, o verdadeiro perdão é impossível. Como a economia e a estratégia política podem esconder muitas violências, é preciso encarar de frente esse paradoxo, essa aporia. É esse paradoxo que faz com que os processos estejam sempre abertos. E, ao contrário do que pode parecer, essa impossibilidade é condição de responsabilidade, é ela que move, é ela que faz com que algo seja sempre buscado, mesmo que não seja nunca alcançado. Diz Derrida (2001, p. 51):

Eu permaneço "rasgado" / "fragmentado" (entre uma visão ética "hiperbólica" do perdão, puro perdão, e a realidade de uma sociedade em funcionamento em processos pragmáticos de reconciliação). Mas sem poder, desejo, ou necessidade para decidir. Os dois polos são irredutíveis, certamente, mas permanecem indissociáveis. Para modular a política, ou o que pode ser chamado "processos pragmáticos", para mudar a lei (a qual, assim, se acha entre dois polos, o "ideal" e o "empírico" - e o que é mais importante para mim é, entre esses dois, essa mediatização universalizadora, essa história da lei, a possibilidade do progresso da lei), é necessário se referir a uma "visão ética 'hiperbólica' do perdão". Mesmo se eu não estou certo das palavras "visão" ou "ética" nesse caso, deixe-me dizer que só essa exigência inflexível pode orientar uma história das leis e a evolução da lei. Isso sozinho pode inspirar aqui, agora, na urgência, sem espera, respostas e responsabilidades.

A partir disso, foi possível perceber como o conceito de perdão de Derrida está relacionado com suas noções sobre ética e justiça. Esses são temas fundamentais na obra derridiana e constituem o núcleo de suas preocupações. O perdão verdadeiro é, para o autor, a possibilidade de agir eticamente, agir com justiça, se é que isso é possível. Muito disso se relaciona a algo que foi dito anteriormente e que está presente em toda sua discussão. Em grande parte, o perdão representa justiça, pois ele não é normativo, nem normalizador. $\mathrm{O}$ perdão, por ser impossível, é extraordinário e, por isso, capaz de romper com o desenrolar natural de uma temporalidade histórica, capaz de se abrir para outro, de recepcionar o outro. Isso remete a outra discussão fundamental em Derrida: a sua concepção de história.

Esse é um tópico fundamental, porque talvez seja o ponto que deixa mais clara a aproximação entre Derrida e Benjamin, já que aqui a influência do último sobre o primeiro é 
clara. Essa influência se dá a partir da noção tão cara a Benjamin do messianismo. Para John Caputo, a desconstrução se relaciona fortemente com a arena messiânica. Esse tom messiânico seria responsável por uma preocupação da desconstrução com relação ao futuro.

Não o relativo e previsível, programável e planejável futuro, mas o futuro absoluto, as boas vindas estendidas para um outro que eu não posso, em princípio, antecipar, o completamente outro, cuja alteridade perturba os círculos complacentes do que é o mesmo (CAPUTO, 1997, p. 156).

Com essa citação fica claro como a desconstrução se relaciona com o futuro e, consequentemente, que tipo de teoria da história está por trás do desconstrucionismo. O messianismo é responsável, em grande parte, por essa ligação.

A noção de messianismo, contudo, não foi aceita logo por Derrida. Ele temia que pudesse transparecer a ideia de um horizonte de possibilidade, mas, sob influência de Benjamin, adota esse termo como um "fraco poder messiânico" ou um "messianismo sem messianismo". Essa virada ao messianismo não agradou aos seus leitores mais secularizados e nietzschianos, porém, como destaca John Caputo, essa torção dá mais sustentação para as críticas de Derrida, inclusive para aquelas voltadas à religião. O autor aponta que a desconstrução poderia ser muito benéfica para as religiões, mantendo-as abertas para reinvenções; religiões que buscassem, então, a justiça, que estivessem abertas ao outro. Ao falar isso, Derrida está querendo se opor aos messianismos fortes e fundamentalistas (não só religiosos), que podem ser catastróficos. O seu messianismo não pertence a um só povo, não pode ser detido como a verdade final, a qual deve ser buscada a qualquer custo. É um messianismo fraco, relaciona-se com a promessa de um futuro absolutamente indeterminado, que está sempre por vir, que não pode chegar nunca.

É fundamental notar que, para Derrida, o tempo messiânico se relaciona com a não presença do Messias, com a promessa de uma vinda que nunca acontecerá, mas na qual é preciso continuar acreditando. Isso se dá porque a presença material do Messias seria desastrosa, já que fecharia a estrutura da esperança, da promessa do futuro. Nesse sentido, o Messias deve estar sempre por vir. O Messias é o completamente outro, despedaça os horizontes estáveis, vai além do que é possível e previsível (CAPUTO, 1997).

A desconstrução, na perspectiva derridiana, é uma paixão pelo impossível, por algo que está sempre por vir, indesconstrutível e impossível. Se na religião o nome desse amor é Deus, na desconstrução assume vários nomes: justiça, hospitalidade, democracia, perdão. Deus é o nome do outro, de qualquer outro, do completamente outro. O messianismo 
democrático é consciente de que qualquer democracia existente não é democrática, a democracia é impossível, por isso, está sempre por vir. O messianismo de Derrida, portanto, não se identifica com a figura do Messias, apenas retém sua futuricidade, o seu por vir (CAPUTO, 1997).

Ao longo da apresentação dessas ideias de Derrida, foi possível perceber como o autor trabalha todos seus conceitos de maneira limítrofe, explorando as suas contradições, aporias, suas possibilidades e impossibilidades. Os conceitos de comunidade, hospitalidade, justiça, perdão e sua concepção de história deixaram isso claro e serviram para perceber o que Derrida pretende dizer ao se referir à desconstrução. A desconstrução é essa ênfase no completamente outro, naquilo que se encontra além dos limites e que é preciso sempre buscar, mesmo sabendo que nunca será totalmente alcançado e que esse alcance seria desastroso. É essa ênfase que liga todos os conceitos trabalhados, ou seja, todos são pensados a partir desse enfoque.

A identidade buscada é sempre uma identidade porosa, auto-diferenciadora, que não se feche em si, sempre aberta ao outro, baseada em uma comunidade sem muros para delimitála, mesmo que isso seja impossível. O que se busca, então, é uma comunidade sem comunidade. A justiça, o elemento indesconstrutível que move a desconstrução é também impossível, porque o justo é sempre inalcançável, mas é isso que move, que força os limites. Apesar de indesconstrutível, o motor da desconstrução, a justiça, não deve ser buscada como um fim, tendo em vista que é impossível. Derrida reivindica, então, que sua impossibilidade seja levada a sério, afinal é nessa aporia que será possível encontrar brechas para a vinda do outro. A ausência de um fim - ou da justiça como um fim - está presente também na sua reflexão sobre o perdão, que é impossível e capaz de romper com a continuidade da história. A ideia de um fim para a história seria, em sua interpretação, a reprodução de uma continuidade, fechada ao outro. Por isso, a história deveria ser messiânica, no sentido de uma futuricidade absoluta, de um por vir, de uma promessa que não pode ser cumprida e, por isso, aberta ao outro. Diante disso já é possível passar para Benjamin e analisar como esses temas são trabalhados por este autor.

\section{Benjamin, a origem, a felicidade e a descontinuidade do tempo}

Nesta parte, os principais objetivos são tentar compreender o pensamento de Benjamin como uma construção teórica do limite, dos paradoxos (talvez próxima à tarefa desconstrucionista), expor a maneira como ele compreende os conceitos importantes para a 
produção deste trabalho e estabelecer relações com as ideias de Derrida. O primeiro ponto a ser explorado aqui é seu importante pensamento sobre a história, através da qual será possível adentrar no tema da identidade, do relacionamento com o outro e da justiça.

Um primeiro conceito importante é o de origem. A princípio a preocupação com a origem parece remeter a uma recusa da modernidade, à exigência de um retorno a uma harmonia precedente ou uma retomada, a partir de projeções, de um paraíso perdido. No entanto, desse ponto de vista, seria difícil compreender Benjamin como um pensador do limite, afinal, a partir de uma preocupação com a origem, seria possível conceber uma relação com ideias de essencialismo ou pureza. No modo de dizer derridiano, isso poderia significar falar de um fechamento para a entrada do outro ou de um autor que se volta para o centro, para a "essência" e não para as fronteiras.

Jeanne Marie Gagnebin (2011), porém, reconstrói a interpretação benjaminiana de origem e é a partir dessa interpretação que tentarei aproximar Walter Benjamin de um pensador do limite. Para Gagnebin, é preciso reconfigurar a interpretação sobre o conceito benjaminiano de origem ou Ursprung. Basicamente, a noção de origem, que serve de sustento para várias reflexões de Benjamin (seja sobre a teoria da alegoria, sobre sua teoria da tradução ou da reprodutibilidade técnica), é pilar para uma teoria da história regida por outra temporalidade, que não aquela linear, progressiva e exterior ao evento. Nesse sentido, a história se aproximaria de uma coleta de informações, o que faria da tarefa do historiador semelhante à do colecionador e não daquele intelectual que tenta estabelecer relações causais entre os fatos do passado. Cada fato histórico seria apresentado em sua unicidade, em sua excentricidade.

A pesquisa historiográfica estaria próxima do estudo do fenômeno, não para descrevêlo de maneira positivista, mas para restituir sua dimensão única e que não pode ser reduzida, buscando, com isso, a preservação do esquecimento e da destruição. A Ursprung, nessa concepção, estaria próxima do sentido de Sprung (salto); a origem seria entendida como salto, pulo para fora da sucessão cronológica e da continuidade do tempo da historiografia tradicional.

Trata-se muito mais de designar, com a noção de Ursprung, saltos e recortes inovadores que estilhaçam a cronologia tranquila da história oficial, interrupções que querem, também, parar esse tempo infinito e indefinido, como relata a anedota dos franco-atiradores, que destroem os relógios na noite da revolução de julho: parar o tempo para permitir o passado esquecido ou recalcado surgir de novo (entspringen, mesmo radical de Ursprung), e ser assim retomado e resgatado no atual (GAGNEBIN, 2011, p. 10). 
Esse salto, essa interrupção da continuidade sem percalços da história, é o que permite que outras histórias, aquelas reprimidas, sejam contadas, ou seja, que o outro possa surgir. Aqui já é possível notar semelhanças entre os dois autores. Para ambos, é a interrupção, a quebra na continuidade, que permite aos outros, aos vencidos surgirem através das brechas abertas.

Então, para Benjamin, a história narrada de forma contínua é responsável, em grande parte, por dificultar outras experiências, por dificultar a expressão das diferenças e por promover a continuidade da dominação e da história dos vencedores.

A tradição ensina-nos que o "estado de exceção" em que vivemos é a regra. Temos de chegar a um conceito de história que corresponda a essa ideia. Só então se perfilará diante dos nossos olhos, como nossa tarefa, a necessidade de provocar o verdadeiro estado de exceção (BENJAMIN, 2012 b, p. 13).

Esse verdadeiro estado de exceção a ser provocado é aquele que excede o tempo contínuo e linear, aquele que rompe a versão da história dos vencedores e é capaz de escutar a voz dos vencidos. O estado de exceção do qual Benjamin fala deve ser buscado nas ruínas, nos cacos e fragmentos da história:

Há um quadro de Klee intitulado Angelus Novus. Representa um anjo que parece preparar-se para se afastar de qualquer coisa que olha fixamente. Tem os olhos esbugalhados, a boca escancarada e as asas abertas. O anjo da história deve ter esse aspecto. Voltou o rosto para o passado. A cadeia de fatos que aparece diante dos nossos olhos é para ele uma catástrofe sem fim, que incessantemente acumula ruínas sobre ruínas e lhas lança aos pés. Ele gostaria de parar para acordar os mortos e reconstituir, a partir dos seus fragmentos, aquilo que foi destruído. Mas do paraíso sopra um vendaval que se enrodilha nas suas asas e que é tão forte que o anjo já não as consegue fechar. Esse vendaval arrasta-o irreparavelmente para o futuro, a que ele volta as costas, enquanto o monte de ruínas à sua frente cresce até o céu. Aquilo a que chamamos de progresso é este vendaval (BENJAMIN, 2012 b, p. 14).

É o progresso, a história contínua e linear, que impede que as ruínas e os fragmentos sejam reconstruídos, é essa continuidade que não permite que os vencidos possam se expressar e que é responsável pelo acúmulo crescente de ruínas.

A partir dessa percepção de história, Benjamin se interessa constantemente pelo atípico, pelo deformado, pelo tortuoso e monstruoso, por aquilo que foge da normalidade e da narrativa progressiva do tempo. Essa atenção ao disforme não é gratuita nem aleatória, mas guiada pela exigência teológica da salvação. Ou seja, trata-se da tentativa de perceber no dado 
histórico a promessa de outra ordem capaz de salvá-lo (GAGNEBIN, 2011). Dessa maneira, a origem não se refere a um ponto inicial, uma lei estrutural, uma arché (parecido com o que Derrida assim denomina) a partir dos quais o fato histórico poderá ser compreendido em sua completude e totalidade. A origem, no sentido benjaminiano, por ser o salto para fora dos limites, é a prova da não realização da totalidade. É como se Benjamin estivesse defendendo uma origem sem origem, para falar em termos similares ao de Derrida. É uma origem que não remete ao ponto inicial, mas que salta para fora do tempo, que quebra com a historicidade.

Para Gagnebin (2011), essa origem funcionaria como indício da totalidade e marca clara de sua falta e, nesse sentido, remeteria a um passado resplandecente, passado de promessa e do possível. Ao mesmo tempo, essa promessa não possuiria nenhuma garantia de ser cumprida. Se essa origem remete a um passado, isso sempre ocorre a partir da rememoração, ou seja, não é possível reencontrar o passado em sua plenitude, não se pode contatá-lo imediatamente. Benjamin, então, diz que o movimento de origem, de salto, só pode ser conhecido como restauração e reprodução e, por isso mesmo, é sempre incompleto. Esse tema da restauração é caro a Benjamin e indica uma vontade de regresso ao passado, mas, inseparavelmente, a precariedade desse regresso, pois "só é restaurado o que já foi destruído (...). A restauração indica, portanto, de maneira inelutável, o reconhecimento da perda, a recordação de uma ordem anterior e a fragilidade desta ordem" (GAGNEBIN, 2011, p. 14). Se a origem se define, em parte, pela restauração é porque é algo incompleto, nunca fechado.

A origem benjaminiana visa, portanto, mais que um projeto restaurativo ingênuo, ela é, sim, uma retomada do passado, mas ao mesmo tempo - e porque o passado enquanto passado só pode voltar numa não-identidade consigo mesmo - abertura sobre o futuro, inacabamento constitutivo (GAGNEBIN, 2011, p. 14).

Ao dizer isso, Gagnebin (2011) está tentando se contrapor à interpretação de que os conceitos de origem e gênese se confundem. A exigência de rememoração do passado não é somente uma restauração do passado, trata-se de uma transformação do presente. A partir disso, é possível notar como a origem na obra benjaminiana não se confunde, de maneira alguma, com a gênese. Enquanto esta última se refere ao ponto zero, a partir do qual tudo se desdobrará e cuja compreensão ou restauração é suficiente para o entendimento da totalidade do desenrolar histórico, a primeira, a origem, é histórica, porque, "paradoxalmente, a restauração da origem não pode cumprir-se através de um retorno às fontes, mas, unicamente pelo estabelecimento de uma nova ligação entre o passado e o presente" (GAGNEBIN, 2011, p. 16). De outro modo, pode-se dizer que a origem é constituída dentro de um contexto 
histórico, ou seja, não há um ponto inicial intocável, uma vez que a origem será sempre reinventada conforme a ligação estabelecida entre passado e presente. Outra coisa que é preciso apreender daí é que a redenção da história não é a volta ao paraíso perdido, mas será sempre dada de maneira contingente, de acordo com as sempre novas relações estabelecidas entre passado e presente. Pensando a partir do prisma mais diretamente político, Benjamin mostra que a narração da historiografia dominante remete ao domínio de uma classe sobre os vencidos. Esta narração coerente deve ser desmontada e a salvação através da origem é sempre uma tarefa de destruição e construção.

Para Gagnebin (2011), a dinâmica da origem não se esgota na restauração do primeiro passo ou do marco zero: a origem é inacabamento e abertura à história, não é a restauração do idêntico, mas a emergência do diferente. Essa estrutura paradoxal é a do instante decisivo do Kairos. O tempo "kairótico" é a temporalidade com a qual Benjamin mais simpatiza. Em oposição ao tempo cronológico, marcado pela continuidade de um tempo progressivo, vazio e homogêneo, que se desenrola a partir de sua própria identidade, o tempo "kairótico" é o tempo da aparição, da revelação do Messias, o tempo da promessa. Essa promessa, como já foi dito, não precisa acontecer, mas o seu tempo imprime uma atitude diferente do tempo cronológico, pois é um tempo aberto, heterogêneo, sem um telos, auto-diferenciador. Nesse sentido, para Benjamin, cabe ao historiador a espera do lampejo, da brecha que pode trazer novas vozes do passado, que guiem as ações no presente, abertas para o que está por vir.

Para o autor, "só o próprio Messias consuma todo o acontecer histórico, nomeadamente no sentido de que só ele próprio redime, consuma, concretiza a relação desse acontecer histórico" (BENJAMIN, 2012a, p. 23). Por isso, Benjamin aponta que nada no campo da história pode, em si mesmo, tentar se relacionar com o messiânico, ou seja, não pode constituir o reino de Deus (só o Messias é capaz disso) como um objetivo da dinâmica histórica. Afinal, o reino de Deus significa não o objetivo, mas o término da dinâmica histórica. Com isso, está subentendida uma crítica à concepção profana da busca pela constituição de um Reino de Deus na Terra ou, seu equivalente, um Reino de Liberdade plena. O que Benjamin faz é separar a ordem do profano, marcada, nesse caso, por uma teleologia e a ordem messiânica ou teológica, que significa o fim ou a interrupção da história. Ele quer apontar para a ausência de uma relação direta dessas duas esferas e, ao mesmo tempo, para a possibilidade de que essas forças se acumulem.

É nesse acúmulo, na mistura dessas duas ordens, que Benjamin enxerga amplas possibilidades. Como a relação entre as duas esferas não é direta e necessária, o pensador tenta trabalhar outras possibilidades de relação que não sejam a de instauração de uma meta 
de consolidação do Reino de Deus na Terra. Para isso, Benjamin (como na sua influência sobre o pensamento de Derrida) reivindica a existência de um fraco messianismo, que se apague na ordem do profano. Investe em uma teologia pequena e feia, como na comparação com o anão da primeira tese sobre a história ${ }^{4}$ ou como nessa citação: "Meu pensamento se comporta para com a teologia da mesma forma do que o mata-borrão para com a tinta. Ele fica totalmente embebido nela. Mas se fosse seguir o mata-borrão, então nada subsistiria daquilo que está escrito" (BENJAMIN, apud GAGNEBIN, 2014, p. 190).

$\mathrm{Na}$ interpretação de Jeanne Marie Gagnebin (2014), essa citação mostra como o pensamento benjaminiano absorve a teologia de uma forma que o texto sagrado se torna dispensável. Ou seja, ela aponta para a fraqueza da teologia e do messianismo de Benjamin. Para a comentadora, isso indica que o messiânico só pode mostrar seu poder quando estiver totalmente imerso no mundo profano, na dinâmica histórica, de forma que "o Messias só virá no momento em que tiver se tornado dispensável" (GAGNEBIN, 2014, p. 191).

A vinda do Messias acontece, então, quando o reino do sagrado e do profano são completamente inseparáveis. Gagnebin (2014) aponta que a palavra alemã Erlösung, que remete à redenção trazida pelo Messias, tem como radical lös (livrar, desatar), o qual aponta para a dissolução, a solução de um problema através de um desaparecimento. Nesse sentido, "se a redenção livra, é porque destrói e dissolve, não porque mantém e conserva" (GAGNEBIN, 2014, p. 192). O que o Messias faz é livrar a oposição entre profano e sagrado, entre histórico e messiânico. É por isso que:

a ordem do profano, que deve ditar a ordem política, é orientada pela ideia da felicidade. Neste sentido bem preciso, poderíamos dizer que, realmente, em Benjamin, a realização messiânica é a realização da felicidade terrestre. Não porque fé religiosa e convicções políticas atuariam no mesmo sentido e em direção à mesma meta (telos), mas porque a atualidade messiânica não se pode enunciar a não ser na prosa liberta, livre, do mundo terrestre (GAGNEBIN, 2014, p. 192).

Os últimos apontamentos podem servir para pensar a ideia de justiça em Walter Benjamin. Eu diria que seu significado se confunde com sua concepção de felicidade,

\footnotetext{
${ }^{4}$ É conhecida a história daquele autômato que teria sido construído de tal maneira que respondia a cada lance de um jogador de xadrez com um outro lance que lhe assegurava a vitória na partida. Diante do tabuleiro, assente sobre uma mesa espaçosa, estava sentado um boneco em traje turco, cachimbo de água na boca. Um sistema de espelhos criava a ilusão de uma mesa transparente de todos os lados. De fato, dentro da mesa estava sentado um anãozinho corcunda, mestre de xadrez, que conduzia os movimentos do boneco por meio de um sistema de arames. É possível imaginar o contraponto dessa aparelhagem na filosofia. A vitória está sempre reservada ao boneco a que se chama "materialismo histórico". Pode desafiar qualquer um se tiver a seu serviço a teologia, que, como se sabe, hoje é pequena e feia e, assim como assim, não pode aparecer à luz do dia (BENJAMIN, 2012 b).
} 
conforme mostrado acima. Uma sociedade considerada justa seria aquela que conseguisse atingir a realização da felicidade terrena. É importante notar que, de forma similar a Derrida, a busca pela felicidade serviria como um motor, um impulso para a movimentação histórica, mas não construiria um objetivo, um telos. Isso ocorre porque a concretização da felicidade corresponde à vinda do Messias, no entanto, como foi visto, o Messias só virá quando sua presença não for necessária. O que se pode depreender disso é que alcançar a plena felicidade é impossível: ela só se realizará quando o Messias vier, mas ele só virá quando não for preciso. Essa contradição, essa aporia, mostra como Benjamin estava atento aos limites, aos caminhos fechados e percebia como eles poderiam fazer a história se mover em busca de sempre outras soluções, nunca completas. Outro elemento a ser destacado é que a consolidação da felicidade, através da redenção propiciada pelo Messias, significa sempre dissolução, destruição. Isso indica que a felicidade é essa constante tarefa de superar e de ir além dos limites, de destruir as barreiras que impedem a vinda do outro - para utilizar uma expressão importante em Derrida e sublinhar, mais uma vez, a semelhança entre os dois pensadores.

Depois de expostas às concepções de história e justiça em Benjamin, é possível passar para a sua noção de identidade (intimamente relacionada com as anteriores). Para adentrar um pouco melhor nesse tema, a partir das lentes benjaminianas, proponho pensar a questão da nação. Benedict Anderson, em seu relevante trabalho chamado "Comunidades imaginadas" (2008), tenta desconstruir a concepção da nação e de identidade nacional como essenciais. Seu esforço é o de revelar as maneiras pelas quais se constroem mecanismos que fazem com que indivíduos que vivem num mesmo país, mas que nunca se viram, e, provavelmente, nunca se verão, possam compartilhar de uma solidariedade, de um sentimento comum de pertença, ou seja, de uma identificação. Sua resposta passa longe de explicações essenciais, que poderiam remeter a uma origem comum, a um espírito nacional ou a características semelhantes dadas quase que naturalmente. Para ele, as nações e esse sentimento de pertencimento e de solidariedade são decorrentes de algo que é imaginado; no sentido de que não existe naturalmente e que é "criado" em meio às dinâmicas da sociedade. Um dos principais elementos que sustentam a nação como uma comunidade imaginada sólida, indissociável e essencial, é a existência de um tempo compartilhado em uma percepção histórica vazia e homogênea, que diz respeito, em parte, à noção de simultaneidade - de que todos os habitantes de uma nação se valem de uma mesma lógica temporal, de que todos partilham ao mesmo tempo da realidade nacional - e também à concepção de progresso - de uma origem comum que explica o presente e guia para o futuro. 
Essa concepção de um tempo vazio, homogêneo, progressivo e linear provém de uma leitura de Walter Benjamin. O que Benedict Anderson faz é notar que essa percepção temporal é fundante da experiência de nação e da identidade nacional, ou seja, a construção da identidade nacional, na perspectiva de Anderson, dependeu fortemente da difusão dessa experiência temporal na Modernidade. Para Benjamin, contar a história com base num tempo cronológico e progressivo é contar a história dos vencedores. É uma história baseada em essências, em identidades fixas, na qual a compreensão de um ponto fundante esclareceria o desenrolar de toda a história, pois ela seria sempre idêntica a si. Benjamin defende uma história feita à contrapelo, que busca o que não foi dito: funcionaria como reveladora das diferenças. A outra história, a dos vencedores, é fundada nas identidades homogêneas e isso dificulta o pronunciamento das diferenças. O que quero dizer com isso é que a própria ideia de nação, baseada numa concepção de origem comum, de um tempo linear e progressivo, é a história contada pelos vencedores, é uma história que dificulta a emergência da diferença (MURICY, 2009).

Como já foi dito anteriormente, a concepção de origem de Benjamin é muito distinta dessa origem que significa um marco zero, um ponto fundamental que revela uma essência. A origem, em Benjamin, é sempre o salto para fora da continuidade, o salto para fora dos limites, em busca do outro, do diferente, de outras possibilidades, sempre transitórias. A partir daí é possível perceber como falar em identidade na obra de Walter Benjamin significa refletir constantemente sobre o que escapa à essência, aquilo que se diferencia dela e que é capaz de abrir buracos nela. Novamente a semelhança com Derrida é perceptível. É preciso pensar em uma forma de agrupamento ou de identidade que esteja além de si, ou seja, de uma identidade não idêntica, que seja sempre diferenciadora.

\section{Considerações finais}

A partir do que foi dito é possível pensar sobre o processo de construção da nação brasileira e, indissociavelmente, sobre a narrativa dessa história. É preciso destacar que esse processo não é unívoco e diz respeito a longas disputas acerca de qual melhor projeto de nação. Apesar da existência desses diversos projetos, duas características parecem comuns a todos eles. A primeira é a elaboração de uma origem, no sentido de um marco fundador, a partir da qual toda história da nação se desenvolveria e o segundo elemento fica claro na expressão "projeto de nação", ou seja, pensar a nação é, também, pensar metas, um fim, um objetivo. 
Essas duas características se relacionam fortemente, uma vez que cada projeto de nação é baseado na construção de um marco fundador, de uma suposta essência, de uma identidade intransponível. Cada uma dessas essências seria refletida em uma característica fundamental do povo brasileiro, um caráter nacional, que varia entre a projeção de um povo alegre, preguiçoso, corajoso, fraco, cordial, receptivo, malandro e por aí vai. Para cada uma dessas identidades, um projeto de nação é associado e uma linha contínua passa a ligar essa origem (como marco fundador), essa identidade, a um objetivo.

Nesse sentido, a história da nação brasileira, em várias vertentes, é contada em uma temporalidade progressiva e teleológica. Isso que poderia parecer natural e sem problemas é objeto de uma profunda tentativa de desconstrução pelos autores trabalhados aqui. Para ambos, a construção de uma narrativa baseada em um tempo vazio e homogêneo, como diria Benjamin, impede que a história seja contada de outras maneiras, o que obstrui o surgimento de outras possibilidades, ou da vinda do outro. Essa possibilidade de narrativa da nação, portanto, não é inocente, ela é fruto e ajuda a frutificar significativas relações de poder. Não fazer parte e não poder contar essa narrativa é uma forma de exclusão. Por isso, Benjamin afirma que a história progressiva e linear é sempre a história dos vencedores. Toda história que não seja aberta a vinda do outro será sempre uma reprodução de relações desiguais de poder, uma história injusta.

Muitas das narrativas hegemônicas da história da nação brasileira costumam compreender as nossas mudanças como lentas, graduais, pacíficas e harmônicas. O desenrolar da nossa história, sob esse ponto de vista, costuma ser fruto de grandes acordos, de ações individuais, de heroísmos etc. Nesse sentido, as violências costumam ser apagadas, deixadas de lado, em prol de uma história de conciliação nacional, de uma história que destaca as grandiosidades e a harmonia. Os traumas, as marcas, as feridas e ruínas deixadas por séculos de colonização, escravidão e, mais recentemente, duas décadas de ditadura militar são minimizados. As vozes daqueles que sofreram com esses episódios é constantemente silenciada, impedindo que a história dos vencidos seja contada.

Buscar a justiça de forma plena, se é que ela existe (como ressalta Derrida), é, diante disso, desconstruir essa temporalidade vazia e homogênea, que reverbera em uma identidade excludente e em uma sociedade injusta, não afeita à diferença. Por isso, aquele episódio, no qual indígenas dispararam flechas contra o relógio que fazia a contagem regressiva para os quinhentos anos do "descobrimento" do Brasil é tão significativo. Em uma manifestação organizada por grupos historicamente excluídos e subalternos da nação brasileira - negros, indígenas, camponeses, operários -, o símbolo que marca a concepção do tempo cronológico 
é atingido. Esse gesto poderia ser interpretado, a partir dos olhos de Benjamin e Derrida, como uma tentativa de quebra daquela historicidade fechada, homogênea. Poderia ser interpretado como uma forma de desconstruir aquela narrativa histórica responsável, em grande parte, pela exclusão daqueles grupos. Poderia ser interpretado como uma crítica ao longo processo de colonização que dizimou a possibilidade de outras histórias serem contadas. Poderia, sobretudo, ser interpretado como uma tentativa de mostrar que uma sociedade justa é aquela que está aberta ao outro, ao diferente, a outras, sempre novas, possibilidades. E, além disso, que essa abertura para o outro não virá como o Messias, pois ele não virá enquanto a felicidade não estiver completa na Terra. Por isso, não basta esperar por um milagre; é preciso acreditar nele, mesmo sabendo que ele é impossível. É preciso estar sempre atento para o que impede a vinda do outro, é preciso manter uma postura ativa para causar as brechas que permitirão a vinda do outro. É preciso, então, buscar constantemente quebrar os relógios e tudo aquilo que representa a repetição, o mais do mesmo e uma barreira para a intromissão do diferente. 


\section{Referências}

ANDERSON, Benedict. Comunidades Imaginadas: reflexões sobre a origem e difusão do nacionalismo. São Paulo: Companhia das Letras, 2008.

BENJAMIN, Walter. Fragmento teológico-político. In: João Barrento (Org.). Walter Benjamin o anjo da história. Belo Horizonte: Autêntica, 2012a, p. 21-24.

Sobre o conceito da História. In: João Barrento (Org.). Walter Benjamin o anjo da história. Belo Horizonte: Autêntica, 2012b, p. 7-20.

CAPUTO, John. Deconstruction in a Nutshell: a conversation with Jacques Derrida. New York, Fordham University Press, 1997.

DERRIDA, Jacques. The gift of death. Chicago \& London: The University Of Chicago Press, 1995.

. On Cosmopolitanism and Forgiveness. Routledge, London and New York, 2001.

. Força de Lei. São Paulo: Livraria Martins Fontes Editora Ltda., 2010.

GAGNEBIN, Jeanne Marie. História e narração em Walter Benjamin. São Paulo: Perspectiva, 2011.

2014.

. Limiar, aura e rememoração: ensaios sobre Walter Benjamin. São Paulo: Editora 34,

LÖWY, Michel. Walter Benjamin: aviso de incêndio: Uma leitura das teses "Sobre o conceito de história". São Paulo: Boitempo, 2005.

MURICY, Katia. Alegorias da Dialética. Rio de Janeiro: NAU, 2009.

Recebido em 10-03-2017;

Revisado em 27-07-2018;

Publicação em 15-12-2018. 